\title{
Technical Note: Evaluating a simple parameterization of radiative shortwave forcing from surface albedo change
}

\author{
R. M. Bright ${ }^{1}$ and M. M. Kvalevåg ${ }^{2}$ \\ ${ }^{1}$ Department of Energy and Process Engineering, Norwegian University of Science and Technology, Trondheim, Norway \\ ${ }^{2}$ Center for International Climate and Environmental Research - Oslo (CICERO), Oslo, Norway
}

Correspondence to: R. M. Bright (ryan.m.bright@ntnu.no)

Received: 14 May 2013 - Published in Atmos. Chem. Phys. Discuss.: 16 July 2013

Revised: 14 October 2013 - Accepted: 27 October 2013 - Published: 18 November 2013

\begin{abstract}
Land-use activities affect Earth's energy balance not only via biogeochemical emissions, but also through perturbations in surface albedo, the latter of which is often excluded in impact assessment studies. In this short technical note, we present and compare a simple model for estimating shortwave radiative forcings at the top of Earth's atmosphere to a more sophisticated 8-stream radiative transfer model based on a discrete ordinate method. Outcomes from monthly albedo change simulations for ten globally distributed regions and a single year revealed that the simple model - based on a single exogenously supplied meteorological variable - performed quite well, having a sample correlation coefficient of 0.93 and a normalized root mean square error of $7.2 \%$. Simple models like the one presented here can offer an attractive and efficient means for non-experts to begin including albedo change considerations in climate impact assessment studies enveloping land use activities.
\end{abstract}

\section{Introduction}

Perturbations in the global energy balance due to changes in land surface albedo are important to consider when attributing climate impacts to policies and product systems originating in the Agriculture, Forestry, and Other Land Use (AFOLU) sectors. However, surface albedo change considerations are typically neglected due to perceived challenges associated with data requirement and radiative transfer model complexity. This is evidenced by the lack of attention given by Working Group III in the previous (Nabuurs et al., 2007; Smith et al., 2007) and upcoming (Mahmood et al., 2013) IPCC Assessment Reports, where reviews of the literature span analyses restricted to application of emission metrics or to biogeochemical concerns following land cover changes in regions where surface albedo is known to be an important contributor to the global energy balance.

In order to study surface albedo changes in global climate models, it is necessary to estimate the attenuation of incoming solar radiation on its way to the surface through the atmosphere. Several numerical approximation techniques have been developed for handling the complexity of scattering and absorption of shortwave radiation. These approaches mostly concern approximations of spectral and spatial resolutions. For highest accuracy, a line-by-line code with radiative transfer calculations for single spectral lines is required, but this is also a comprehensive and time-consuming method. The most common method in global climate modeling is to solve the radiative transfer equation numerically when shortwave radiation is propagating in discrete directions (decided by a specified number of streams), called the discrete ordinate method (DOM) (Chandrasekhar, 1960) and the electromagnetic spectrum is divided into spectral broad bands. The twostream and delta-Eddington (Joseph et al., 1976) approximations are examples of simplified versions of this method, and particularly the DIScrete Ordinates Radiative Transfer program (DISORT) (Stamnes et al., 1988) has been developed to provide a numerical solution of DOM.

While many radiative transfer models and codes are freely available, they require significant expertise and rely on a suite of exogenously prescribed surface, cloud, meteorological, and atmospheric characteristics obtained from other sources (Oreopoulos et al., 2012). Here, we present a simple model for estimating top-of-atmosphere (TOA) shortwave radiative forcings from a surface albedo change and benchmark results 
from several albedo change simulations to those generated by a more advanced 8-stream radiative transfer model based on DISORT.

\section{Model description}

In recent years, NASA's Surface Meteorological and Solar Energy (SSE) project (NASA, 2013a) and Prediction of Worldwide Energy Resource (POWER) projects (NASA, 2013b) have been providing internet-based access to parameters specifically tailored to assist studies of agroclimatology, sustainable urban development, and renewable energy deployment. The main goal of the SSE and POWER projects has been to make NASA's satellite data more readily accessible to the general academic community, where such data have been demonstrated to enhance the output of existing decision support systems. The parameters currently available through the SSE and POWER web-based data archive are based primarily on solar radiation derived from satellite observations and meteorological data from the Goddard Earth Observing System assimilation model (Global Modeling and Assimilation Office, 2013). Gridded radiation budget variables are accessible at a 1 by $1^{\circ}$ spatial resolution dating back to 1983 and have been tested/validated against research quality observations from the Baseline Surface Radiation Network (BSRN) (Ohmura et al., 1998).

These data provision and validation efforts lend support to the exploration and development of simpler models built to rely on such data for addressing questions surrounding land cover albedo changes and their subsequent shortwave energy balance perturbations. Several recent studies employ simple models to estimate albedo change forcings at the top-of-theatmosphere (TOA), where multiple scattering and absorption of incoming solar radiation throughout a 1-layer atmosphere are accounted for either through the use of an atmospheric transmittance factor or by directly adopting estimates of the incoming solar radiation flux at surface level (Cherubini et al., 2012; Meyer et al., 2012; Kirschbaum et al., 2011, 2013; Bright et al., 2012; VanCuren, 2012; Bright et al., 2013). Using Cherubini et al. (2012) as an example, local radiative forcings at TOA are computed with a simple model that relies on a single clearness index parameter, $K_{T}(t)$, obtained from Nasa SSE/POWER:

$\mathrm{RF}_{\mathrm{TOA}}^{\text {Simple }}(t, i)=-R_{\mathrm{TOA}}(t, i) K_{T}(t, i) \Delta \alpha_{\mathrm{s}}(t, i) T_{\mathrm{a}}$,

where $-R_{\mathrm{TOA}}(t, i)$ is the local incoming extraterrestrial solar flux at TOA in time step $t$ and region $i$, which is a function of latitude, $K_{T}(t, i)$ is the fraction of local $-R_{\mathrm{TOA}}$ that reaches the surface in time step $t$ ("all-sky clearness index") and region $i$, which may be considered the downwelling transmittance coefficient for the single atmospheric layer, $\Delta \alpha_{\mathrm{s}}(t, i)$ is the local change in surface albedo in time step $t$ and region $i$, and $T_{\mathrm{a}}$ is a constant denoting the globally averaged annual fraction of upwelling shortwave radiation exiting a clear sky, which is around 80-85\% (Lenton and Vaughan, 2009; Kiehl and Trenberth, 1997). A value of 0.854 (Lenton and Vaughan, 2009) for $T_{\mathrm{a}}$ was applied in Cherubini et al. (2012) and the forcing results using this simple parameterization aligned well with those calculated using a more sophisticated radiative transfer model (Fu-Liou, 2005; Fu and Liou, 1992, 1993) that required detailed prescriptions of cloud and aerosol optical properties. Although $-R_{\mathrm{TOA}}(t)$ may be applied with $K_{T}(t)$ to compute the incident flux at surface, $-R_{\mathrm{S}}(t, i)$, this surface flux could also be taken directly from Nasa SSE/POWER for similar spatial $(1 \times 1$ degree $)$ and temporal resolutions (monthly, 1983-2005):

$\operatorname{RF}_{\mathrm{TOA}}^{\text {Simple }}(t, i)=-R_{\mathrm{S}}(t, i) \Delta \alpha_{\mathrm{s}}(t, i) T_{\mathrm{a}}$,

where $-R_{\mathrm{S}}(t, i)$ is the incident surface flux in time step $t$ for region $i, \Delta \alpha_{\mathrm{s}}(t)$ the difference between the new surface albedo and the reference albedo at time step $t$ and region $i$, and $T_{\mathrm{a}}$ is the upwelling transmittance constant $(0.854)$.

Recognizing that such simple parameterizations can appear to provide reasonable forcing estimates, we subject Eq. (2) to additional scrutiny here by performing idealized albedo-change simulations for 10 globally distributed regions and compare the results to those of a more sophisticated eight-stream radiative transfer model (Myhre et al., 2002, 2007) based on DISORT (Stamnes et al., 1988), which has been applied in several recent modeling studies (Myhre et al., 2005; Eide et al., 2013; Skeie et al., 2011; Samset and Myhre, 2011). To our knowledge, outcomes from such simple models have not been compared quantitatively to those generated via application of more advanced models.

The chosen case regions experience a broad range of incoming solar radiation and background atmospheric conditions influenced by aerosol and cloud optical properties, shown in Table 1. Urban and tropical deforestation areas with historically high concentrations of anthropogenic aerosols from both biomass burning and fossil fuel combustion are selected for the simulations, as well as urban areas with low cloud cover and non-urban areas with low anthropogenic aerosol concentration. Additional details are found in Table 1.

For the 8-stream DISORT model, TOA shortwave forcings are calculated in $3 \mathrm{~h}$ time steps and averaged into daily and monthly means. Forcing simulations are run using prescribed 2004 meteorological data from the European Centre for Medium-range Weather Forecasts (ECMWF) with aerosol data based on simulations from a chemical transport model (Oslo-CTM2) involved in a global aerosol model intercomparison study (Myhre et al., 2013). Aerosols included are sulphate, black carbon, and organic carbon from fossil fuel and biomass burning. For each case region, the 2004 MODIS black-sky albedo (MCD43) for the representative pixel is decreased by 0.1 in the idealized forcing simulation.

For the "simple" model presented as Eq. (2) - henceforth referred to as Simple - monthly mean $R_{\mathrm{S}}$ is taken directly 
Table 1. Case study regions and their center pixel geographic coordinates.

\begin{tabular}{|c|c|c|c|c|}
\hline Region & Latitude & Longitude & Site Description & Reference \\
\hline Northeast China & 35 & 115 & $\begin{array}{l}\text { High aerosol concentration } \\
\text { from urban sources }\end{array}$ & Henriksson et al. (2011) \\
\hline West Bengal, India & 23 & 87 & $\begin{array}{l}\text { High aerosol concentration } \\
\text { from urban sources }\end{array}$ & Henriksson et al. (2011) \\
\hline Melbourne, Australia & -37.8 & 145 & Urban, medium cloud cover & NASA (2012) \\
\hline Ivory Coast, Africa & 7 & -7.5 & $\begin{array}{l}\text { High aerosol concentration } \\
\text { from biomass burning }\end{array}$ & $\begin{array}{l}\text { Hai and Liu (1994); } \\
\text { Roberts et al. (2009) }\end{array}$ \\
\hline $\begin{array}{l}\text { Amazonia, Brazil, } \\
\text { S. America }\end{array}$ & -11.9 & -52.5 & $\begin{array}{l}\text { High aerosol concentration } \\
\text { from biomass burning }\end{array}$ & $\begin{array}{l}\text { Hai and Liu (1994); } \\
\text { Sena et al. (2013) }\end{array}$ \\
\hline $\begin{array}{l}\text { Rust Belt, Midwestern } \\
\text { USA }\end{array}$ & 40.5 & -80 & $\begin{array}{l}\text { High aerosol concentrations } \\
\text { from urban sources }\end{array}$ & Leibensperger et al. (2012) \\
\hline Saskatchewan, Canada & 55.2 & -106.5 & Rural, high cloud cover & NASA (2012) \\
\hline Phoenix, AZ, USA & 33.2 & -111.5 & Urban, low cloud cover & NASA (2012) \\
\hline Bavaria, Germany & 48.7 & 11.5 & Urban, high cloud cover & NASA (2012) \\
\hline Central Finland & 61.5 & 23.5 & Rural, high cloud cover & NASA (2012) \\
\hline
\end{tabular}
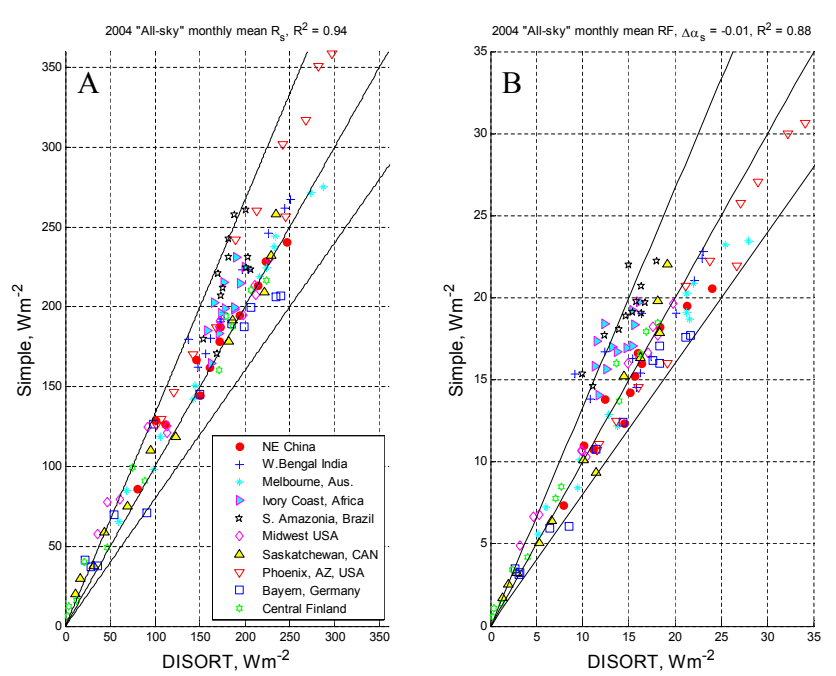

Fig. 1. (A) Correlation between the incoming monthly mean surface solar flux $R_{\mathrm{S}}(\mathrm{B})$ and monthly shortwave radiative forcings at TOA computed by the Simple and DISORT models.

from NASA SSE for the same year and region (NASA, 2013a).

\section{Results and discussion}

Figure 1a shows the variation in the 2004 all-sky monthly mean surface radiation flux $R_{\mathrm{S}}$ between the two models, with the majority of the fluxes falling within $\pm 25 \%$ agreement of each other. There is good agreement between mod- els $\left(R^{2}=0.94\right)$, although the Simple model - adopting $R_{\mathrm{S}}$ directly from NASA SSE - has slightly higher $R_{\mathrm{S}}$ fluxes relative to the DISORT model.

A site-by-site comparison of monthly $R_{\mathrm{S}}$ presented in Table 2 reveals that these fluxes are generally higher overall for the Simple relative to the DISORT model, with increasing deviation linked to months with lower incoming extraterrestrial solar radiation - such as in winter (summer) for northern (southern) latitudes.

When monthly $R_{\mathrm{S}}$ fluxes are directly compared with ground observations for two of our case regions - "Midwest USA" and "Saskatchewan, Canada" - we find evidence that DISORT may actually be underestimating $R_{\mathrm{S}}$ in winter months, and that, overall, the Simple model generates estimates closer to the ground-based observation (blue) more frequently than DISORT (red) for these two regions, presented in Fig. 2.

Because the $R_{\mathrm{S}}$ fluxes estimated by both models seem to correlate well overall with ground observation, the results of the Simple model are henceforth compared and discussed only in relation to the results of DISORT.

In terms of monthly shortwave radiative forcing at TOA from the -0.1 surface albedo change, the Simple model (Fig. 1b) agrees well $\left( \pm 25 \%, R^{2}=0.88\right)$ with DISORT (Fig. 1b), indicating that use of the constant term $T_{\mathrm{a}}$ in the Simple model appears to produce reasonable estimates. Nevertheless, ordinary least squares regression is performed using monthly TOA output from the DISORT model as the response variable for assessing the suitability of the $T_{\mathrm{a}}$ constant used in the Simple model: 
Table 2. The "all-sky" monthly mean incoming solar surface flux $\left(R_{\mathrm{S}}\right)$ of the Simple model relative to DISORT (shown as \% deviation from DISORT). Correlation coefficients $(r)$ are also presented.

\begin{tabular}{|c|c|c|c|c|c|c|c|c|c|c|c|c|c|}
\hline & Jan & Feb & Mar & Apr & May & Jun & Jul & Aug & Sep & Oct & Nov & Dec & $r$ \\
\hline N.E. China & 28.6 & 14.3 & 8.9 & 2.2 & -2.5 & -0.5 & 0.7 & 0.9 & 4 & -3.6 & 13.4 & 7.1 & 0.98 \\
\hline W. Bengal, India & 11.3 & 13 & 8.7 & 7.1 & 6.6 & 9.5 & 10.6 & 30.6 & 9.3 & 10.9 & 10.5 & 9.3 & 0.98 \\
\hline Melbourne, Australia & -4.3 & 4.4 & 0.9 & -0.2 & 0.2 & 9.9 & 24.6 & 11.7 & 4.1 & -0.1 & 2.3 & -0.6 & 0.99 \\
\hline Ivory Coast, Africa & 21.1 & 10 & 12.6 & 22 & 22 & 7 & 1.1 & 17.4 & 11.5 & 5 & 5.6 & 13 & 0.75 \\
\hline Amazonia, Brazil & 0.9 & 16.6 & 19.6 & 20.2 & 29.3 & 27 & 33.3 & 29.6 & 36.7 & 7.9 & 13.3 & 11.6 & 0.67 \\
\hline Midwest, USA & 67.8 & 35.8 & 10.2 & 9.2 & -2.1 & 1.3 & 1.4 & -1.7 & 10.7 & 6.7 & 31.9 & 60.9 & 0.99 \\
\hline Saskatchewan, Canada & 78.6 & 35.2 & 116 & 2.8 & -5.6 & 9.9 & 1.4 & -2.1 & -3.7 & 9.3 & 18.7 & 70.8 & 0.99 \\
\hline Phoenix, AZ, USA & 21.5 & 19.5 & 27.5 & 24.7 & 24.3 & 20.5 & 18 & 4.4 & 21.9 & 11.4 & 21.1 & 24 & 0.98 \\
\hline Bavaria, Germany & 88.9 & 29.1 & 28.3 & 2.4 & -3.3 & -13.8 & -12.4 & -5.8 & -2.8 & -21.6 & 4 & 29 & 0.98 \\
\hline Central Finland & 191.9 & 91.7 & 33.4 & 8.5 & 1.8 & -3.4 & 0.3 & -6.3 & 2.2 & 6.2 & 37.3 & 135.9 & 0.99 \\
\hline
\end{tabular}

Table 3. The "all-sky" monthly mean shortwave radiative forcing (RF) of the Simple model relative to DISORT (shown as \% deviation from DISORT) after a simulated -0.1 surface albedo change. Correlation coefficients $(r)$ are also presented.

\begin{tabular}{|c|c|c|c|c|c|c|c|c|c|c|c|c|c|}
\hline & Jan & Feb & Mar & Apr & May & Jun & Jul & Aug & Sep & Oct & Nov & Dec & $r$ \\
\hline W. Bengal, India & -5.4 & -5.1 & -4.8 & -2.4 & -1.2 & 16.2 & 34.6 & 67.8 & 27.5 & 5.9 & -5.7 & -8 & 0.86 \\
\hline Ivory Coast & 22.5 & 17.7 & 24.7 & 48.1 & 49.9 & 24.3 & 20.1 & 39.7 & 28.9 & 14.6 & 10.5 & 21.8 & 0.68 \\
\hline Amazonia, Brazil & 31.6 & 54.4 & 43.3 & 29.2 & 28.4 & 17.7 & 26.7 & 23.2 & 46.7 & 16.9 & 25.1 & 23.9 & 0.88 \\
\hline Midwest, USA & 42 & 7.8 & 8 & 7.5 & -2.2 & -1 & 3.7 & -2.5 & 1.3 & -0.4 & 28.4 & 53.4 & 0.99 \\
\hline Bavaria, Germany & 29.9 & -7.6 & -5.6 & -8.1 & -7.1 & -18.5 & -16.8 & -12.5 & -13.3 & -28.7 & 2.1 & 2 & 0.99 \\
\hline Central Finland & 161.3 & 44.5 & 10.4 & 2.1 & 6.6 & 2.1 & 17.1 & -1.9 & 9.8 & 5.3 & 17.5 & 91.2 & 0.99 \\
\hline
\end{tabular}
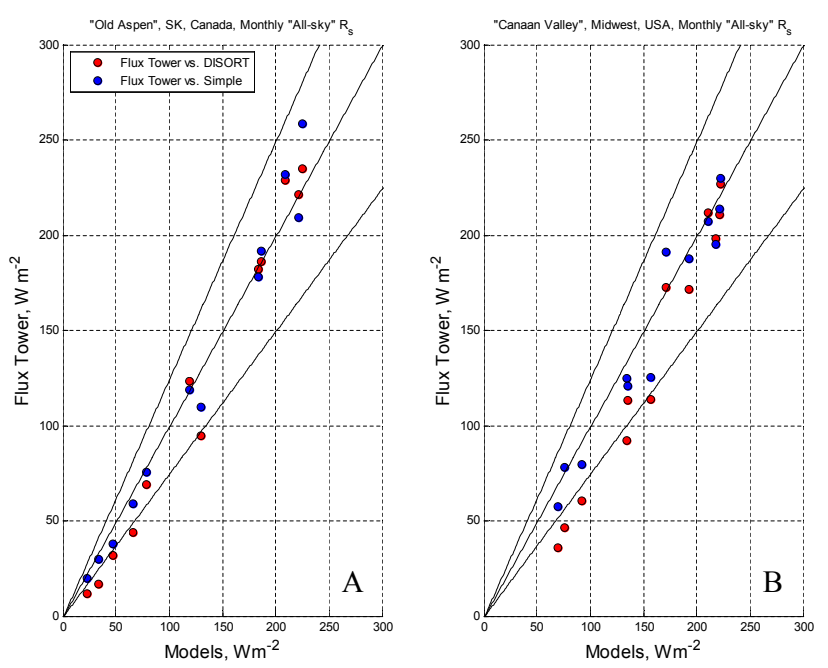

Fig. 2. Modeled vs. observed monthly mean "All-sky" $R_{\mathrm{S}}$ for the two case study regions: (A) "Saskatchewan, Canada" and (B) "Midwest USA". Observed $R_{\mathrm{S}}$ data for each case region are based on the "Old Aspen" flux tower site located at $53.2^{\circ} \mathrm{N},-106.2^{\circ} \mathrm{W}$ Barr and Black, 2013) and the "Canaan Valley" flux tower site located at $39.1^{\circ} \mathrm{N},-79.4^{\circ} \mathrm{W}$ (Meyers, 2013), respectively.
$\mathrm{RF}_{\mathrm{TOA}, i}^{\mathrm{DISORT}}=k_{0}+k_{1}\left(-R_{\mathrm{S}, i} \Delta \alpha_{\mathrm{S}}\right)+\varepsilon_{i}$,

where the slope estimator $k_{1}$ is analogous to the $T_{\mathrm{a}}$ term of Eq. (2), $k_{0}$ is the intercept estimator, and $\varepsilon_{i}$ denotes the $i$ th residual, or error. Minimizing the sum of squared residuals results in an estimator of 0.857 for $k_{1}$, with the sum of squared error (SSE) and coefficient of determination $\left(R^{2}\right)$ equal to the original model. In other words, use of the global mean upwelling transmittance factor 0.854 in the Simple model appears robust and its replacement with 0.857 not justified.

A site-by-site inspection of RF outcomes of the Simple model relative to DISORT (Table 3) reveals that higher RF estimates are mostly restricted to those regions and months with high aerosol concentrations from biomass combustion or low extraterrestrial incoming solar radiation. Regions and months where the Simple model tends to generate lower forcings relative to the DISORT model are those in which clear- and all-sky solar radiation fluxes at surface are similar (i.e., from low cloud cover), such as "Phoenix, AZ, USA", which experiences an arid climate. For this region, the Simple model underestimates forcings despite the relative overestimation of the incoming solar flux at surface level 
(Table 2), implying that the value of the constant term $T_{\mathrm{a}}-$ which is based on the global annual mean - might be too low for this and perhaps other arid regions. Increasing the precision of the Simple model will ultimately require knowledge of local upwelling atmospheric transmittance in place of $T_{\mathrm{a}}$, which can be computed if spatially explicit information on upwelling absorptivity and reflectivity are known (Winton, 2005).

\section{Conclusions}

Overall, 96 out of the 120 monthly forcings estimates derived using the Simple model fell within $\pm 25 \%$ of the estimates calculated using the more advanced DISORT radiative transfer scheme. On average, compared to DISORT, the Simple model tended to overestimate radiative forcings by $+3.7 \%$ and had a normalized RMSE of $7.2 \%$, although a comparison of the modeled $R_{\mathrm{S}}$ flux with ground-based $R_{\mathrm{S}}$ observation for two of our study regions suggests that DISORT may be underestimating this flux and thus potentially radiative forcings.

For applications where this relative model deviation may be considered acceptable in estimates of shortwave radiative forcings at TOA, we find it difficult to conclude that the additional time and expertise required to run more sophisticated transfer codes like DISORT are justified when simpler alternatives based on high-quality, easily accessible meteorological data are available. Simple models like the one presented here can offer an attractive and efficient means for non-experts to begin including albedo change considerations in climate impact assessment studies enveloping land-use activities.

Acknowledgements. We are grateful for the constructive feedback provided by three anonymous reviewers.

Edited by: J. Brandt

\section{References}

Barr, A. and Black, A.: Saskatchewan BERMS Old Aspen Site Gapfilled Meterological Dataset in, available online: http://fluxnet. ornl.gov (last access: July 2013) from Oak Ridge National Laboratory Distributed Active Archive Center (ORNL DAAC), Oak Ridge, Tennessee, USA, 2013.

Bright, R. M., Cherubini, F., and Strømman, A. H.: Climate Impacts of Bioenergy: Inclusion of Temporary Carbon Cycle and Albedo Change in Life Cycle Impact Assessment, Environmental Impact Assessment Review, 37, 2-11, 2012.

Bright, R. M., Antón-Fernández, C., Astrup, R., Cherubini, F., Kvalevåg, M. M., and Strømman, A. H.: Climate change implications of shifting forest management strategy in a boreal forest ecosystem of Norway, Glob. Change Biol., doi:10.1111/gcb.12451, in press, 2013.
Chandrasekhar, S.: Radiative Transfer, Dover Publications, New York, 1960.

Cherubini, F., Bright, R. M., and Strømman, A. H.: Site-specific global warming potentials of biogenic $\mathrm{CO} 2$ for bioenergy: contributions from carbon fluxes and albedo dynamics, Environ. Res. Lett., 7, 045902, doi:10.1088/1748-9326/7/4/045902, 2012.

Eide, M. S., Dalsøren, S. B., Endresen, Ø., Samset, B., Myhre, G., Fuglestvedt, J., and Berntsen, T.: Reducing $\mathrm{CO}_{2}$ from shipping - do non- $\mathrm{CO}_{2}$ effects matter?, Atmos. Chem. Phys., 13, 41834201, doi:10.5194/acp-13-4183-2013, 2013.

$\mathrm{Fu}$, Q. and Liou, K. N.: On the Correlated k-Distribution Method for Radiative Transfer in Nonhomogeneous Atmospheres, J. Atmos. Sci., 49, 2139-2156, doi:10.1175/15200469(1992)049<2139:otcdmf>2.0.co;2, 1992.

$\mathrm{Fu}, \mathrm{Q}$. and Liou, K. N.: Parameterization of the Radiative Properties of Cirrus Clouds, J. Atmos. Sci., 50, 2008-2025, 1993.

Fu-Liou: Fu-Liou online 200507 (Diurnal Simulation), http: //www-cave.larc.nasa.gov/cgi-bin/cave/fuliou/sun/flsun.cgi (last access: February 2011), 2005.

Global Modeling and Assimilation Office: The GEOS-5 System, http:/gmao.gsfc.nasa.gov/GEOS/ (last access: April 2013), 2013.

Hai, W. M. and Liu, M.-H. Spatial and temporal distribution of tropical biomass burning, Global Biogeochem. Cy., 8, 495-503, 1994.

Henriksson, S. V., Laaksonen, A., Kerminen, V.-M., Räisäänen, P., Järvinen, H., Sundström, A.-M., and de Leeuw, G.: Spatial distributions and seasonal cycles of aerosols in India and China seen in global climate-aerosol model, Atmos. Chem. Phys., 11, 79757990, doi:10.5194/acp-11-7975-2011, 2011.

Joseph, J. H., Wiscombe, W. J., and Weinman, J. A.: The Delta-Eddington Approximation for Radiative Flux Transfer, J. Atmos. Sci., 33, 2452-2459, doi:10.1175/15200469(1976)033<2452:tdeafr>2.0.co;2, 1976.

Kiehl, J. T. and Trenberth, K. E.: Earth's Annual Global Mean Energy Budget, B. Am. Meteorol. Soc., 78, 197-208, 1997.

Kirschbaum, M. U. F., Whitehead, D., Dean, S. M., Beets, P. N., Shepherd, J. D., and Ausseil, A.-G. E.: Implications of albedo changes following afforestation on the benefits of forests as carbon sinks, Biogeosciences, 8, 3687-3696, doi:10.5194/bg-83687-2011, 2011.

Kirschbaum, M. U. F., Saggar, S., Tate, K. R., Thakur, K. P., and Giltrap, D. L.: Quantifying the climate-change consequences of shifting land use between forest and agriculture, Sci. Total Environ., 465, 314-324, doi:10.1016/j.scitotenv.2013.01.026, 2013.

Leibensperger, E. M., Mickley, L. J., Jacob, D. J., Chen, W.-T., Seinfeld, J. H., Nenes, A., Adams, P. J., Streets, D. G., Kumar, N., and Rind, D.: Climatic effects of 1950-2050 changes in US anthropogenic aerosols - Part 1: Aerosol trends and radiative forcing, Atmos. Chem. Phys., 12, 3333-3348, doi:10.5194/acp-12-33332012, 2012.

Lenton, T. M. and Vaughan, N. E.: The radiative forcing potential of different climate geoengineering options, Atmos. Chem. Phys., 9, 5539-5561, doi:10.5194/acp-9-5539-2009, 2009.

Mahmood, R., Pielke, R. A., Hubbard, K. G., Niyogi, D., Dirmeyer, P. A., McAlpine, C., Carleton, A. M., Hale, R., Gameda, S., Beltrán-Przekurat, A., Baker, B., McNider, R., Legates, D. R., Shepherd, M., Du, J., Blanken, P. D., Frauenfeld, O. W., Nair, U. S., and Fall, S.: Land cover changes and their biogeophysical ef- 
fects on climate, Int. J. Climatol., doi:10.1002/joc.3736, in press, 2013.

Meyer, S., Bright, R. M., Fischer, D., Schulz, H., and Glaser, B.: Albedo Impact on the Suitability of Biochar Systems To Mitigate Global Warming, Environ. Sci. Technol., 46, 12726-12734, doi:10.1021/es302302g, 2012.

Meyers, T.: Ameriflux Canaan Valley Site Meterological Dataset, http://fluxnet.ornl.gov (last access: July 2013) from Oak Ridge National Laboratory Distributed Active Archive Center (ORNL DAAC), Oak Ridge, Tennessee, USA, 2013.

Myhre, G., Jonson, J. E., Bartnicki, J., Stordal, F., and Shine, K. P.: Role of spatial and temporal variations in the computation of radiative forcing due to sulphate aerosols: A regional study, Q. J. Roy. Meteorol. Soc., 128, 973-989, doi:10.1256/0035900021643610, 2002.

Myhre, G., Kvalevåg, M. M., and Schaaf, C. B.: Radiative forcing due to anthropogenic vegetation change based on MODIS surface albedo data, Geophys. Res. Lett., 32, L21410, doi:10.1029/2005GL024004, 2005.

Myhre, G., Bellouin, N., Berglen, T. F., Berntsen, T. K., Boucher, O., Grini, A., Isaksen, I. S. A., Johnsrud, M., Mishchenko, M. I., Stordal, F., and Tanré, D.: Comparison of the radiative properties and direct radiative effect of aerosols from a global aerosol model and remote sensing data over ocean, Tellus B, 59, 115-129, 2007.

Myhre, G., Samset, B. H., Schulz, M., Balkanski, Y., Bauer, S., Berntsen, T. K., Bian, H., Bellouin, N., Chin, M., Diehl, T., Easter, R. C., Feichter, J., Ghan, S. J., Hauglustaine, D., Iversen, T., Kinne, S., Kirkevåg, A., Lamarque, J.-F., Lin, G., Liu, X., Lund, M. T., Luo, G., Ma, X., van Noije, T., Penner, J. E., Rasch, P. J., Ruiz, A., Seland, Ø., Skeie, R. B., Stier, P., Takemura, T., Tsigaridis, K., Wang, P., Wang, Z., Xu, L., Yu, H., Yu, F., Yoon, J.-H., Zhang, K., Zhang, H., and Zhou, C.: Radiative forcing of the direct aerosol effect from AeroCom Phase II simulations, Atmos. Chem. Phys., 13, 1853-1877, doi:10.5194/acp-13-18532013, 2013.

Nabuurs, G. J., Masera, O., Andraskso, K., Benitez-Ponce, P., Boer, R., Dutschke, M., Elsiddig, E., Ford-Robertson, J., Frumhoff, P., Karjalainen, T., Krankina, O., Kurz, W. A., Matsumoto, M., Oyhantcabal, W., Ravindranath, N. H., Sanz Sanchez, M. J., and Zhang, X.: Forestry, in: Climate Change 2007: Mitigation. Contribution of Working Group III to the Fourth Assessment Report of the Intergovernmental Panel on Climate Change, edited by: Metz, B., Davidson, O. R., Bosch, P. R., Dave, R., and Meyer, L. A., Cambridge University Press, Cambridge, UK, New York, NY, USA, 541-584, 2007.

NASA: Surface meteorology and Solar Energy (SSE) Release 6.0 Methodology, http://earth-www.larc.nasa.gov/solar/documents/ SSE6Methodology.pdf (last access: May 2013), NASA Atmospheric Science Data Center, 2013a.

NASA: Prediction of Worldwide Energy Resource (POWER), NASA Langley Research Center, http://power.larc.nasa.gov/ common/php/POWER_AboutPOWER.php (last access: May 2013), 2013b.
Ohmura, A., Gilgen, H., Hegner, H., Müller, G., Wild, M., Dutton, E. G., Forgan, B., Fröhlich, C., Philipona, R., Heimo, A., König-Langlo, G., McArthur, B., Pinker, R., Whitlock, C. H., and Dehne, K.: Baseline Surface Radiation Network (BSRN/WCRP): New Precision Radiometry for Climate Research, B. Am. Meteorol. Soc., 79, 2115-2136, doi:10.1175/1520-0477(1998)079<2115:bsrnbw>2.0.co;2, 1998.

Oreopoulos, L., Mlawer, E., Delamere, J., Shippert, T., Cole, J., Fomin, B., Iacono, M., Jin, Z., Li, J., Manners, J., Räisänen, P., Rose, F., Zhang, Y., Wilson, M. J., and Rossow, W. B.: The Continual Intercomparison of Radiation Codes: Results from Phase I, J. Geophys. Res.-Atmos., 117, D06118, doi:10.1029/2011jd016821, 2012.

Samset, B. H. and Myhre, G.: Vertical dependence of black carbon, sulphate and biomass burning aerosol radiative forcing, Geophys. Res. Lett., 38, L24802, doi:10.1029/2011g1049697, 2011.

Sena, E. T., Artaxo, P., and Correia, A. L.: Spatial variability of the direct radiative forcing of biomass burning aerosols and the effects of land use change in Amazonia, Atmos. Chem. Phys., 13, 1261-1275, doi:10.5194/acp-13-1261-2013, 2013.

Skeie, R. B., Berntsen, T. K., Myhre, G., Tanaka, K., Kvalevåg, M. M., and Hoyle, C. R.: Anthropogenic radiative forcing time series from pre-industrial times until 2010, Atmos. Chem. Phys., 11, 11827-11857, doi:10.5194/acp-11-11827-2011, 2011.

Smith, P., Martino, D., Cai, Z., Gwary, D., Janzen, H., Kumar, P., McCarl, B., Ogle, S., O'Mara, F., Rice, C., Scholes, B., and Sirotenko, O.: Agriculture, in: Climate Change 2007: Mitigation. Contribution of Working Group III to the Fourth Assessment Report of the Intergovernmental Panel on Climate Change, edited by: Metz, B., Davidson, O. R., Bosch, P. R., Dave, R., and Meyer, L. A., Cambridge University Press, Cambridge, UK, and New York, NY, USA, 497-540, 2007.

Stamnes, K., Tsay, S. C., Wiscombe, W., and Jayaweera, K.: Numerically stable algorithm for discrete-ordinate-method radiative transfer in multiple scattering and emitting layered media, Appl. Opt., 27, 2502-2509, 1988.

VanCuren, R.: The radiative forcing benefits of "cool roof" construction in California: quantifying the climate impacts of building albedo modification, Climatic Change, 112, 1071-1083, doi:10.1007/s10584-011-0250-2, 2012.

Winton, M.: Simple optical models for diagnosing surfaceatmosphere shortwave interactions, J. Climate, 18, 3796-3806, 2005. 